\title{
PENERAPAN METODE PEMBELAJARAN THINK-PAIR- SHARE-SQUARE DI KELAS TPB-ITS UNTUK MENINGKATKAN KEMAMPUAN MEMBACA BAHASA INGGRIS MAHASISWA
}

\author{
Endang Susilowati \\ Arfan Fahmi
}

\begin{abstract}
ABSTRAK
Tujuan pembelajaran Bahasa Inggris di ITS menurut Kurikulum Tahun 2010 2014 adalah mahasiswa diakhir proses pembelajaran dapat membaca, memahami, meringkas, dan mempresentasikan teks berbahasa Inggris, serta menyimak dan memahami materi berbahasa Inggris tentang sain dan teknologi. Pada pelaksanaan pembelajaran Bahasa Inggris di ITS yang secara administrasi diselenggarakan oleh TPB ( Tahun Persiapan Bersama), ada beberapa kendala sering dijumpai, seperti ukuran kelas yang relatif besar dengan 40 sampai 60 mahasiswa, dan kemampuan membaca mahasiswa yang relatif heterogen. Agar supaya kegiatan pembelajaran Bahasa Inggris menjadi efektif untuk meningkatkan kemampuan pembelajar dalam memahami wacana tulis berbahasa Inggris mahasiswa maka metoda yang tepat untuk tindakan kelas di TPB adalah metode pembelajaran think-pair-share-square. Metode pembelajaran tersebut didasarkan pada prinsip-prinsip kerjasama (cooperative learning), yaitu metode pembelajaran yang diterapkan pada kelas yang mempunyai perbedaan kemampuan pada individu-individu anggotanya dengan membentuk kelompokkelompok kecil sehingga memungkinkan terjadinya kerjasama dan saling membantu antar anggota kelompok dalam menyelesaikan tugas pembelajaran yang diberikan (Jacob, 1999:3). Prinsip kerjasama (cooperative learning) menitikberatkan pada interaksi pembelajar dan antara pembelajar dan pengajar.
\end{abstract}

Kata Kunci : Tujuan Pembelajaran Bahasa Inggris di ITS, Kurikulum ITS 20102014, Kelas TPB, Metode Pembelajaran think-pair-share-square, Prinsip kerjasama cooperative learning

Perkembangan sains dan teknologi dewasa ini terjadi begitu cepat, misalnya telepon genggam yang mungkin lima belas tahun yang lalu masih dalam proses pengolahan ide sekarang dapat kita rasakan betapa hampir setiap minggu muncul produk baru dengan tawaran fitur-fitur yang lebih inovatif untuk memuaskan konsumen. Dunia Maya (internet) yang dulu merupakan andalan sistem komunikasi Angkatan Bersenjata Amerika Serikat, sekarang anak SD pun dapat memanfaatkannya.

Akselerasi perkembangan teknologi ini sangat erat kaitannya dengan kemampuan kognisi manusia dalam mempersepsi dan mengolah informasi serta menformulasi dan mewujudkan ide-ide inovatif yang dapat meningkatkan taraf kehidupannya. 
Kemampuan mempersepsi dan mengolah informasi tercermin dari kemampuan seorang individu dalam menerima informasi baik visual, audial, maupun audiovisual yang selanjutnya akan diolah dan disimpan di memori permanen dalam otaknya. Informasi yang tersimpan tersebut selanjutnya akan digunakan dalam proses penciptaan ide-ide dan perwujudannya, (Carrol:1999,104)

Kemampuan membaca merupakan kemampuan mempersepsi informasi yang berbentuk tulisan yang selanjutnya akan diolah dan disimpan dalam otak dalam proses kognisi. Dengan kemampuan membaca yang baik seorang individu akan lebih mudah mewujudkan keinginannya untuk hidup yang lebih baik. Misalnya, seorang petani yang berkeinginan untuk meningkatkan hasil panennya, akan lebih mudah terwujud jika ia mau membaca tulisan-tulisan tentang pertanian dibandingkan dengan yang tidak membaca. Begitu pula seorang mekanik yang ingin mengerti dan menguasai struktur mesin mobil baru, ia akan lebih cepat menguasainya jika ia membaca berbagai tulisan tentang mesin mobil tersebut dibandingkan dengan yang tidak membaca. Dengan demikian membaca merupakan salah satu alat pemerolehan pengetahuan yang sangat penting bagi seorang individu dalam mempertahankan dan mengembangkan eksistensi kehidupannya.

Perkembangan sains dan teknologi menuntut indvidu-individu yang terlibat di dalamnya untuk berkemampuan membaca yang baik sehingga dapat berperan aktif dalam perkembangan tersebut. Sehubungan dengan hal tersebut, Celce-Muercia dan Obstain menyatakan bahwa dalam perkembngan sains dan teknologi, membaca merupakan salah satu kebutuhan pokok seorang individu karena banyak sekali pemuasan rasa keingintahuannya dapat diperoleh dalam bentuk wacana tulis khususnya yang berbahasa Inggris dengan proses membaca (Celce-Muercia dan Obstain, 2000:118). Dengan demikian, membaca dapat mengantar seseseorang menuju kehidupan yang lebih baik. Pertanyaannya sekarang, bagaimana membaca terutama dalam bahasa Inggris itu dapat diajarkan di kelas-kelas dalam pendidikan formal?

Bahasa Inggris di Indonesia telah diajarkan secara formal mulai tingkat sekolah dasar (SD), terutama di daerah perkotaan yang memuat bahasa Inggris 
pada kurikulumnya. Bahkan sekarang Taman Kanak Kanak pun menyelenggarakan program bahasa Inggris bagi pembelajarnya. Instruksi Presiden nomer 28 tahun 1990 tentang Pendidikan Dasar menyatakan bahwa kurikulum suatu Sekolah Dasar boleh memuat mata pelajaran yang mencerminkan kebutuhan lokal masyarakat di mana sekolah itu berada. Sehingga penyelenggaraan mata pelajaran bahasa Inggris di Sekolah Dasar ditafsirkan sebagai muatan lokal kurikulum sekolah tersebut (Huda, 1999:134). Lain halnya di SLTP, bahasa Inggris sudah merupakan mata pelajaran wajib yang harus diselenggarakan oleh setiap SLTP di Indonesia.

Sejalan dengan terselenggaranya mata pelajaran bahasa Inggris mulai tingkat SD, pelajaran membaca juga berawal dari tahap tersebut. Tujuan pelajaran membaca dalam bahasa Inggris di Pendidikan Tingkat Dasar (SD), Menengah (SLTP) dan Lanjutan (SMU) adalah :

1. untuk mendapatakan informasi secara umum dalam wacana tulis.

2. untuk mendapatakan informasi secara khusus dalam wacana tulis.

3. untuk memperoleh pemaknaan dan penggunaan unsur leksikal bahasa Inggris dalam membaca.

Usaha pencapaian tujuan tersebut diintegrasikan dengan keterampilan berbahasa yang lain seperti menyimak, berbicara, dan menulis (Pusat Kurikulum 2002).

Bagaimana halnya di tingkat Pendidkan Tinggi? Undang-Undang Sistem Pendidikan Nasional nomer 20 Tahun 2003 menyatakan bahwa bahasa merupakan salah satu muatan nasional di Perguruan Tinggi. Dengan kedudukan tersebut bahasa Inggris diajarkan di seluruh Perguruan Tinggi di Indonesia.

\section{DISKRIPSI MASALAH}

Pembelajaran mata kuliah bahasa Inggris di Perguruan Tinggi untuk jurusan non bahasa termasuk dalam rumpun Mata Kuliah berkehidupan bermasyarakat (MBB) yang berbobot 2 (dua) satuan kredit semester(SKS), dalam kurikulum yang berbasis kompetensi( Competence Base ) maupun Contextual Teaching Learning(CTL). Tujuan dari mata kuliah tersebut adalah untuk 
membekali mahasiswa dengan teknik membaca yang baik agar dapat memahami wacana tulis berbahasa Inggris dalam bidang keahlian yang dipelajarinya. Hal tersebut dianggap penting untuk menunjang proses studi mahasiswa tersebut selanjutnya. Selain itu Mahasiswa yang merupakan luaran (output) dari Sekolah Menengah (SMU dan SMK) belum mempunyai kemampuan memahami bacaan dengan baik dikarenakan oleh kurangnya penguasaan kosa kata dan tata bahasa serta kebiasaan memahami bacaan secara harfiah yang mengandalkan makna leksikal suatu kata tanpa mencoba memahami makna gramatikanya (Sutarsyah, 2000)

Tujuan pembelajaran Bahasa Inggris di ITS menurut Kurikulum Tahun 2010 - 2014 adalah mahasiswa diakhir proses pembelajaran dapat membaca, memahami, meringkas, dan mempresentasikan teks berbahasa Inggris, serta menyimak dan memahami materi berbahasa Inggris tentang sain dan teknologi. Pada pelaksanaan pembelajaran Bahasa Inggris di ITS yang secara administrasi diselenggarakan oleh TPB ( Tahun Persiapan Bersama ), ada beberapa kendala sering dijumpai, seperti ukuran kelas yang relatif besar dengan 40 sampai 60 mahasiswa, dan kemampuan membaca mahasiswa yang relatif heterogen. Hal tersebut dikarenakan dalam setiap kelas TPB, pembelajar terdiri dari mahasiswa berbagai jurusan dengan input yang berbeda. Masalah lain adalah karena faktor ruang kuliah dan pengajar yang terbatas maka ada beberapa kelas dalam kegiatan pembelajaran bahasa Inggris dilaksanakan pada jam ke 5-6 / 7-8 (yaitu jam1 $1^{00}$ $12^{40} / 13^{00}-14^{40}$ ). Hal tersebut memberi inspirasi penulis untuk mengujicobakan metode pembelajaran think-pair-share-square di kelas agar kegiatan pembelajaran Bahasa Inggris menjadi efektif, dan sebagai upaya meningkatkan kemampuan pembelajar dalam memahami wacana tulis berbahasa Inggris. Serta menerapkan pendekatan kooperatif (coopertive learning) untuk mengatasi masalah-masalah yang akan timbul pada kelas heterogen dalam tingkat kemampuan berbahasa pembelajar/pesertadidik ditingkat pendidikan tinggi.

Metode pembelajaran tersebut didasarkan pada prinsip-prinsip kerjasama (cooperative learning), yang menurut Jacob mempunyai pengertian sebagai metode pembelajaran yang diterapkan pada kelas yang mempunyai perbedaan 
kemampuan pada individu-individu anggotanya dengan membentuk kelompokkelompok kecil sehingga memungkinkan terjadinya kerjasama dan saling membantu antar anggota kelompok dalam menyelesaikan tugas pembelajaran yang diberikan (Jacob, 1999:3)

Metode ini memungkinkan mahasiswa untuk dapat bekerja sama dalam kelompok, saling bertukar gagasan, pengetahuan dan strategi untuk memecahkan masalah yang dihadapinya dalam membaca. Mereka akan memperoleh kesempatan yang lebih luas untuk berdiskusi dan mengungkapkan pendapatnya dalam kelompok kecil. Selain itu, dengan metode pembelajaran ini masing-masing peserta didik (mahasiswa) akan memperoleh kesempatan yang sama dalam aktifitas pembelajaran walaupun kemampuan membaca mereka berbeda-beda (Lie, 2002)

Metode ini mempunyai 5 ciri positif yaitu ketergantungan positif antar anggota kelompok (positive interdependence), pembentukan kelompok (team formation), akuntabilitas (accountability), ketrampilan sosial (social skills), dan proses pembelajaran yang terstruktur (structured intructional learning process) (Kessler 1992:8).

Karena menganut prinsip-prinsip kerjasama (cooperative learning) metode ini menitikberatkan pada interaksi antar peserta didik (pembelajar) dan antara peserta didik dan pendidik (pengajar). Interaksi tersebut dapat dibangun dengan melibatkan peserta didik dalam aktifitas pembelajaran individual dan kelompok yang diawasi oleh pendidik dengan menggunakan jurnal mingguan pembelajar (individual weekly journal) yang selalu dikumpulkan setiap akhir pertemuan kelas.

Pemilihan metode ini bisa untuk melihat tindakan kelas yang diuji keefektifannya dengan kemampuan memahami wacana tulis berbahasa Inggris dari tindakan kelas didasarkan pada alasan-alasan sebagai berikut:

1. Metode pembelajaran ini dapat membantu pembelajar (mahasiswa) dalam mengembangkan pemahaman konseptual suatu topik bahasan, kemampuan memilah informasi dan menyimpulkannya,dan kemampuan menelaah 
suatu informasi dari sudut pandang yang lain. (Florida Curriculum Framework, 1996)

2. Metode ini sangat bermanfaat karena dapat menyusun tahapan diskusi dengan baik. Dalam penerapan metode ini pembelajar akan mengikuti proses pembelajaran yang terstruktur sehingga akan mengurangi perilaku di luar pembelajaran (off-task behavior). Selain itu, Akuntabilitas akan dapat terjaga karena setiap pembelajar akan melaporkan hasil intepretasinya kepada temannya yang selanjutnya akan melaporkannya kepada kelas (Jones, 2002)

3. Dalam penerapan metode ini pengajar (dosen) tidak mendominasi kelas seperti pada metode ceramah. Peran pengajar hanya sebagai fasilitator, moderator, pembimbing dan pengamat yang selalu menjaga agar proses pembelajaran sesuai dengan satuan pembelajaran.

4. Beberapa pakar pendidikan mengungkapkan bahwa kekuatan metode pembelajaran ini terletak pada kemampuannya meningkatkan partisipasi pembelajar dibandingkan dengan metode klasikal (ceramah dan menjawab pertanyaan baik secara lisan maupun tulisan di papan) (Lie, 2002:56)

5. Adanya kenyataan di lapangan bahwa ukuran kelas yang relatif besar pada mata kuliah bahasa Inggris (40-60 pembelajar dalam satu kelas), sehingga dengan penerapan metode ini diharapkan pengajar dapat lebih menguasai kelas dan memonitor perkembangan proses pembelajaran.

6. Adanya kenyataan bahwa kemampuan membaca pembelajar yang beragam dalam satu kelas sehingga dengan penerapan metode ini diharapkan terjadi saling pertukaran pengetahuan dan strategi belajar antar pembelajar.

Berdasarkan paparan di atas, penulis menganggap perlu untuk mengadakan pengamatan atau penelitian tindakan kelas untuk menguji keefektifan metode pembelajaran think-pair-share-square dalam proses pengembangan kemampuan memahami wacana tulis berbahasa Inggris pembelajar (mahasiswa) pada mata kuliah bahasa Inggris di kelas TPB - ITS Surabaya.

\section{KONSEPTUALISASI}


Pada bagian ini akan dipaparkan konseptualisasi yang beekenaan dengan metode pembelajaran think-pair-share-square. Paparan itu akan dibagi menjadi empat bagian. Bagian pertama akan menjelaskan konseptualisasi membaca. Bagian kedua memaparkan konseptualisasi pembelajaran membaca. Bagian ketiga mengupas konseptualisasi metode pembelajaran kooperatif sebagai induk dari teknik pembelajaran think-pair-share square yang dilanjutkan dengan pemaparan penelitian tindakan kelas (Classroom Action Research). Sedangkan pada bagian terakhir akan dilaporkan hasil penelitian-penelitian terakhir yang berkaitan dengan teknik pembelajaran think-pair-share square.

\section{Konsep Membaca}

Membaca dapat mengandung dua arti. Pertama, membaca dapat diartikan sebagai aktifitas melafalkan lambang bunyi sebagaimana dapat kita lihat pada kegiatan anak-anak dalam belajar membaca. Kedua, membaca mencakup aspek aktifitas pemerolehan informasi melalui tulisan. Pengertian pertama menjadi cakupan fonetik terutama orthografi yang mencoba merepresentasikan bunyibunyi bahasa ke dalam simbol-simbol (huruf-huruf). Pengertian kedua menarik perhatian para ahli linguistik kependidikan (educational linguistics), psikolinguistik maupun neorolinguistik karena berhubungan dengan wacana tulis (written text), pembaca (reader), dan konteks (situasi, tujuan, maksud dan sebagainya). Linguistik kependidikan berkepentingan untuk mencari jawaban atas pertanyaan-pertanyaan yang berhubungan dengan bagaimana memberdayakan pembaca terutama dalam mempergunakan kemampuan bahasa. Keduanya untuk membaca dengan menformulasikan aktifitas-aktifitas pembelajaran yang sesuai dengan kondisi pembaca, lingkungan dan maksud serta tujuan pembelajaran membaca tersebut. Psikolinguistik mengkaji aktifitas perilaku pembaca dan faktor-faktor psikologis yang mempengaruhi proses membaca. Sedangkan neurolinguistik mencoba melihat kondisi otak manusia dalam hubungannya dengan aktifitas membaca. 
Tulisan ini berada dalam koridor linguistik kependidikan yang berupaya mengujicobakan metode pembelajaran think-pair-share-square dalam kelas membaca bahasa kedua (bahasa Inggris)

Dalam linguistik kependidikan membaca didefinisikan sebagai suatu proses penyimpulan dan pembentukan makna melalui interaksi dengan wacana tulis secara simultan (Snow, 2002:11). Ada empat elemen dalam definisi tersebut yaitu penyimpulan makna, pembentukan makna, interaksi dengan wacana tulis, dan simultan. Keterkaitan keempat unsur tersebut dapat diuraikan secara sederhana sebagai berikut: dengan berinteraksi dengan wacana tulis, penyimpulan makna dilakukan oleh pembaca untuk memampatkan pemahamannya tentang bacaan yang dibacanya yang kemudian akan terbentuk suatu susunan makna dalam memorinya secara simultan (Snow, 2002:11-13 dan Hood, et al 1999:27).

\section{Konsep Pembelajaran Membaca}

Pembelajaran membaca yang baik merupakan alat yang paling efektif untuk mengembangkan kemampuan memahami wacana tulis dan menghindari masalah-masalah membaca. Pembelajaran membaca dapat meningkatkan kemampuan menyerap oleh pembaca dari suatu bacaan.Pembelajaran membaca yang tepat dapat memberikan kesempatan kepada pembelajar untuk memperoleh pengetahuan dan mencapai tujuan-tujuan emosional maupun intelektualnya.(Snow, 2002:29).

Pembelajaran membaca yang baik harus mencakup aspek-aspek yang berhubungan dengan pembaca, teks, tujuan kegiatan, dan konteks. Proses pembelajaran membaca di kelas hendaknya bersifat dinamis dan interaktif (Snow, 2002:30 dan Brown, 2001:313).

Lebih lanjut Brown menyatakan ada dua macam pembelajaran membaca di dalam kelas yaitu membaca dengan keras (oral reading) dan membaca dengan tidak bersuara (silent reading). Membaca dengan keras menitikberatkan pada kemampuan pembelajar untuk melafalkan bunyi-bunyi bahasa dan biasanya sering diterapkan pada pembelajar pemula bahasa kedua. Membaca dengan tidak 
bersuara dibagi lagi menjadi tiga macam yaitu membaca secara intensif (intensive reading) dan membaca secara ekstensif (extensive reading).

Membaca secara intensif merupakan suatu aktifitas kelas dengan mefokuskan pembahasan mengenai unsur-unsur linguistik dan semantik suatu wacana tulis. Pembelajaran ini menggiring pembelajar untuk memperhatikan bentuk-bentuk tata bahasa, penanda wacana, dan detil-detil struktur permukaan bahasa lainnya untuk memahami suatu teks. Pembelajaran semacam ini sangat cocok digunakan pada kelas yang mengintegrasikan teks dengan pembelajaran tata bahasa melalui membaca.

Membaca secara ekstensif merupakan suatu aktifitas membaca untuk mencapai pemahaman secara umum (general understanding). Aktifitas ini biasanya dilakukan di luar kelas dan melibatkan teks-teks panjang seperti buku, artikel, dan laporan. Pembelajaran semacam ini dapat merupakan salah satu bentuk tugas di luar kelas pada pelajaran yang menfokuskan pada pemahaman suatu ilmu (content-based instruction) (Brown, 2001:311-3)

Tindakan kelas dalam pembelajaran bahasa Inggris dikelas TPB-ITS ini dalam koridor membaca secara intensif (intensive reading) karena dua faktor, sebagai berikut :

1. Kelas TPB merupakan kelas yang memfokuskan pada ketrampilan membaca (skilled-based instruction) bukan pada pemahaman isi suatu ilmu (contentbased instruction)

2. Kelas TPB mengintegrasikan teks sebagai bahan acuan pembelajaran tata bahasa.

Brown, (Brown, 2001:313-5) menyatakan ada beberapa hal yang harus diperhatikan dalam menyususun pembelajaran membaca yang interaktif, sebagai berikut :

1. Tidak memberikan porsi berlebih terhadap salah satu teknik pembelajaran saja. Hal tersebut mengindikasikan bahwa dalam satu pertemuan kelas sangat dimungkinkan pengajar menggunakan berbagai macam teknik pembelajaran untuk mencapai tujuan pembelajaran. 
2. Menggunakan teknik yang dapat memotivasi pembelajar. Teknik pembelajaran hendaklah dirancang sedemikian rupa sehingga menarik pembelajar untuk mengikutinya dengan seksama. Hal tersebut misalnya dapat dilakukan dengan pendekatan pengalaman bahasa (Language Experience Approach - LEA)) di mana pembelajar dilibatkan dalam penyususnan materi ajar (usulan wacana tulis) yang akan dibahas di kelas sesuai dengan pengalaman kebahasaan mereka.

3. Menyeimbangkan aspek keaslian (authenticity) dan keterjangkauan pemahaman bacaan (readability) dalam pemilihan materi ajar (teks). Penyusunan bahan ajar secara bertahap dapat dimulai dari teks-teks yang disimpulkan, disederhanakan, dan kemudian teks-teks asli.

4. Mendorong penggunaan berbagai macam strategi membaca. Penggunaan berbagai macam strategi membaca dalam satu proses pembelajaran akan memberikan kesempatan yang luas bagi pembelajar untuk menentukan strategi mana yang paling cocok baginya sesuai dengan tujuan membacanya dan untuk ragam wacana tulis yang dibacanya.

5. Melibatkan teknik membaca bawah-atas (bottom-up reading) dan atasbawah (top-down reading). Teknik bawah-atas dimulai dari teks (bawah) sebagai penyedia informasi yang diambil oleh pembaca (atas) melalui proses membaca. Sedangkan teknik atas-bawah dimulai dari pembaca (atas) yang ingin mendapatkan informasi dengan terlebih dahulu menggunkan pengetahuan yang telah diperolehnya untuk mendapatkannya di dalam teks (bawah) dalam proses membaca.

6. Mengikuti alur SQ3R (Survey, Question, Read, Recite, Review). Survey, pembaca membaca dengan melihat sepintas untk mencari pokok pikiran utama sutu teks. Question, pembaca menyususn daftar pertanyaan yang ingin diketahuinya dalam teks tersebut. Read, pembaca membaca teks sambil mencari jawaban atas pertanyaan-pertanyan yang ia susun sebelumnya. Recite, pembaca mencoba menceritakan kembali apa yang telah dibacanya dalam bentuk lisan maupun tulisan. Review, mengulangi 
kembali apa yang telah ia dapat dan mencoba mengendapkannya untuk pemahaman jangka panjang.

7. Membagi aktifitas pembelajaran menjadi tiga bagian yaitu aktifias sebelum membaca (pre-reading), aktifitas disaat membaca (during reading) dan aktifitas setelah membaca (post-reading). Aktifitas pembelajaran dalam pre-reading dapat berupa pengenalan topik bacaan yang akan dibahas, pengaktifan pengetahuan pembaca tentang topik tersebut dan penyusuanan daftar pertanyaan yang ingin diketahui pembaca dalam teks tersebut. Aktifitas pembelajaran dalam during reading dapat berupa pengidentifikasian unsur-unsur tata bahasa yang menjadi fokus pembelajaran, pengidentifikasian penanda wacana, dan pencarian jawaban atas daftar pertanyaan sebelumnya. Aktifitas pembelajaran dalam postreading dapat berupa menjawab pertanyaan membahas kosa kata, mendiskusikan tujuan penulis dan alur pemikiran yang digunakan, melatih penggunaan struktur tata bahasa tertentu, dan mengarahkan pembelajar untuk latihan menulis sebagai aktifitas selanjutnya (follow up activity)

8. Membuat dan menyusun beberapa unsur evaluasi dalam penerapan pembelajaran tersebut. Hal tersebut dapat dilakukan dengan membuat checklist tentang pembelajar dan kedaan kelas selama proses pembelajaran itu berlangsung.

\section{Konsep Metode Pembelajaran Kooperatif}

Ada empat unsur yang terlibat dalam proses pembelajaran di kelas yaitu pengajar, pembelajar, bahan ajar, dan interaksi. Keterpaduan empat unsur tersebut sangat menentukan keberhasilan suatu upaya pembelajaran. Dalam metode pembelajaran kooperatif, unsur interaksi menjadi tema sentral. Pembelajaran ini dibangun atas interaksi antar pembelajar dan pembelajar dengan pengajar. Singkatnya, pembelajar akan menerima pembelajaran dari pengajar yang kemudiana bersama pembelajar yang lain berusaha menyelesaikan tugas-tugas pembelajaran yang diberikan (Brown, 2001:164). 
Dalam pembelajaran model ini ada lima peran penting pengajar dalam menentukan keberhasilan pembelajaran, yaitu sebagai:

1. pembimbing (concellor)

2. pengarah (director)

3. pengatur (manager)

4. fasilitator(facilitator)

5. nara sumber (resource)

Kelima peran tersebut hendaklah dilaksanakan sesuai dengan tuntutan situasi yang berkembang selama pembelajaran di kelas berlangsung (Brown, 2001:167-9)

Dalam interaksi antar pembelajar dalam pengujicobaan teknik think-pairshare-square, pembelajar akan mengikuti tahapan pembelajaran sebagai berikut:

1. Think, pembelajar menyusun daftar pertanyaan yang ingin diketahuinya setelah membaca sekilas teks dan mencoba menjawab pertanyaan-pertanyaan tersebut setelah membaca teks dengan seksama. Pembelajar juga akan diberikan daftar pertanyaan oleh pengajar serta tugas tugas lain yang berhubungan dengan pembelajaran untuk dijawabnya. Ketiga aktifitas tersebut dilakukan sendiri.

2. Pair, pembelajar bersama dengan teman di sampingnya akan membahas pertanyaan pertanyaan baik yang disusun oleh kedua pembelajar tersebut maupun yang diberikan oleh pengajar. Mereka juga diharapkan saling berdiskusi mengenai kesulitan-kesulitan yang mereka alami selama membaca, misalnya struktur kalimat dan kosa kata.

3. Share, dalam tahapan kedua di atas dua pembelajar akan berbagi informasi tentang isi bacaan dan pemahaman masing-masing serta kesulitan-kesulitan yang dialaminya.

4. Square, empat pembelajar dengan mengatur tempat duduknya membentuk segi empat (square) mendiskusikan tugas-tugas yang mereka telah laksanakan dan meringkasnya yang kemudian akan dipresentasikannya di kelas oleh salah seorang wakil. 
Beberapa keuntungan yang dapat diperoleh dengan pembelajaran model ini (Brown, 2001: 178-9) antara lain:

1. menghasilkan proses pembelajaran bahasa yang interaktif

2. membuat iklim pembelajaran yang efektif.

3. mengedepankan tanggung jawab dan otonomi pebelajar

4. menghindarkan dari pembelajaran yang bersifat individual.

\section{Penelitian Tindakan Kelas (Classroom Action Research)}

Penelitian tindakan kelas merupakan suatu usaha meningkatkan kualitas pendidikan dengan cara melibatkan pengajar dalam upaya sadarnya mengantisipasi perubahan yang terjadi.

Ada dua pendekatan dalam penelitian model ini, pendekatan empiris dan pendekatan intepretatif. Pendekatan empiris memandang perlu bukti-bukti (data) yang didapat dalam penelitian ini diuji kesahihannya. Pendekatan ini beranggapan bahwa data yang sahih itu hanyalah data yang dapat ditangkap oleh panca indera. Implikasi pandangan tersebut dalam pendidikan menghasilkan suatu pandangan bahwa gejala proses pendidikan itu sama dengan gejala alam yang terkadang tidak dapat dijamah oleh rekayasa manusia, dengan demikian peran pengamat (observer) dalam penelitian ini sangat bermanfaat untuk merekam seluruh kejadian yang terjadi dalam tindakan kelas. (McNiff, 1998:23). Sebaliknya, pendekatan intepretatif memandang pengamat dan praktisi (pengajar) sebagai sumber data yang sama-sama penting. Keduanya harus sepakat tentang tindakantindalan yang akan diambil untuk meningkatkan kualitas pembelajaran dalam kelas (McNiff, 1998:25-6). Dalam hal ini peneliti bersandar pada pandangan intepretatif dan akan melibatkan pengamat secara bersama-sama memutuskan tindakan-tindakan kelas yang akan dilakukan .

Model penelitian tindakan kelas ini akan membuka kesempatan bagi pengajar untuk mendapatkan pengetahuan tentang tugas-tugasnya secara pribadi dan profesi. Penelitian ini dapat menghasilkan sesuatu yang berarti dan dapat menggerakkan roda perubahan dari cara-cara tradisional ke cara-cara yang lebih progresif. 
Prosedur yang akan dilalui dalam penelitian ini dibagi ats 4 tahap. Tahapan tersebut yaitu: perencanaan (planning), tindakan (acting), pengamatan (observing), dan refleksi (reflecting). Prosedur tersebut membentuk suatu sikllus yang berputas dan akan berhenti jika tujuan pembelajran telah tercapai (McNiff:1998:32-5)

Berikut ini adalah penjeasan tahapan penelitian tindakan kelas tersebut:

a. Perencanaan (Planning)

Pada tahapan ini rencana-rencana tindakan dalam kelas yang akan dilaksanakan dlam upaya mencari penyelesaian suatu masalah kelas disusun. Penyusunan tersebut meliputi materi ajar, media, dan teknik pembelajaran.

b. Tindakan (Acting)

Segala rencana yang telah disusun pada tahap perencanaan akan diterapkan dalam tahapan ini semaksimal mungkin untuk mencapai tujuan pembelajaran.

c. Pengamatan (Observing)

Pengamat akan memperhatikan secara seksama hal-hal yang terjadi di dalam kelas selama penerapan tindakan kelas itu dilaksanakan. Pada tahap ini lembar observasi dan catatan lapangan akan digunakan untuk merekam data.

d. Refleksi (Reflecting)

Pada tahap ini praktisi (pengajar) dan pengamat bekerja sama mengevalusi tindakan kelas yang telah dilaksanakan dan menentukan perubahan-perubahan yang akan diambil pada siklus tindakan berikutnya.

\section{Penelitian-Penelitian terkait Metode Pembelajaran Think-Pair-Share-Square}

Berikut ini akan dipaparkan beberapa penelitian terakhir yang berkaitan dengan penelitian ini.

1. Martha, A Ianchu dalam TESOL Journal Volume 9 nomor 2 summer 2000 melaporkan penggunaan metode pembelajaran kooperatif dengan kerja kelompok dengan menitikberatkan kepada aktifitas pelancaran pertama (fluency first activity)di kelas English for Academic Purposes (EAP) bagi pembelajar bukan penutur asli sejak tahun 1997 di University of Oregon Amerika Serikat. Menurutnya, dengan metode ini, pembelajar akan 
merasa terbiasa dengan beban bacaan (reading load) yang berat dengan saling bertukar pikiran melalui kerja kelompok serta dapat meningkatkan kemampuan peserta pebelajar.

2. Pauline Gibbons dalam TESOL Quarterly Volume 37 nomor 2 Summer 2003 melaporkan peranan pengajar sebagai fasilitator dalam interaksinya dengan pembelajar di kelas content-based yang dapat mengarahkan kemampuan berbahasa pembelajar sesuai dengan target pembelajaran. Interaksi tersebut dipersiapkan sedemikian rupa untuk memancing pembelajar untuk bertukar pikiran dengan temannya dalam suatu kelompok kerja.

3. May Shih dalam TESOL Journal Volume 8 nomor 4 winter 1999 melaporkan keberhasilan penerapan pendekatan komunikatif dalam pengajaran bahasa Inggris dengan melibatkan pebelajar dalam interaksi kelompok di negara-negara Asia seperti Cina, Thailand dan Vietnam. Ia juga mengkaji aspek-aspek kultural psikilogis masyarakat Asia dalam kaitannya dengan kemungkinan penerapan metode tersebut.

4. Keiko Hayashi dalam RELC Journal Volume 30 nomor 2 Desember 1999 melaporkan adanya keterkatian yang sangat erat antara strategi membaca yang digunakan pembelajar dengan pembelajaran membaca dam membaca ekstensif (extensive reading). Studi ini dilakukan di Universitas Kansai Gaidai Jepang pada kelas bahasa Inggris bagi jurusan non-bahasa Inggris.

5. Rod Ellis, Yoshihiro Tanaka, dan Asako Yamazaki dalam Jurnal Language Learning Volume 44 Nomor 3 September 1999 melaporkan bahwa interaksi dalam kelas antar pembelajar yang baik dapat memacu pencapaian kemampuan membaca bahasa kedua dengan baik. Penelitian ini dilakukan di Universitas Temple Jepang.

\section{Kesimpulan}

Metode pembelajaran think-pair-share-square merupakan salah satu alternative pada pembelajaran di kelas TPB - ITS Surabaya sebagai upaya untuk meningkatkan kemampuan pembelajar dalam memahami wacana tulis berbahasa 
Inggris. Salah satu upaya penerapkan pendekatan kooperatif (coopertive learning) untuk mengatasi masalah-masalah yang akan timbul pada kelas heterogen dalam tingkat kemampuan berbahasa pembelajar/pesertadidik ditingkat pendidikan tinggi. Serta upaya untuk mengatasi problem ukuran kelas yang relatif besar dalam mata kuliah bahasa Inggris (40-60 pembelajar dalam satu kelas), sehingga dengan penerapan metode ini diharapkan pengajar dapat lebih menguasai kelas dan memonitor perkembangan proses pembelajaran, dengan demikian proses pembelajaran menjadi lebih efisien.

\section{DAFTAR PUSTAKA}

Brown, Douglas, H. 2001. Teaching by Principles. An Interactive Approach to Language Pedagogy. (2 $2^{\text {nd }}$ Edition). New York. Addison Wesley Longman.

Carrol, D. 1999 The Psychology of Language, New York . Pergamon Press,.

Celce-Murcia, M and Olshtain, E. 2000 Discourse and Content in Language Teaching, A Guide for Language Teachers, Cambridge, Cambridge University Press.

Departemen Pendidikan Nasional. 2003 Undang Undang no 30 tahun 2003 tentang SISDIKNAS, Sistem Pendidikan Nasional.

Ellis, Rodd. Et. al. 1999. Classroom Interaction: Comprehension and the Aqcuisition of L2 Words Meanings dalam Language Learning, A Journal of Research in Language Studies. Vol 44 no: 3

Florida Curriculum Framework, 1996.

Gibbons, P. 2003. Mediating Language Learning, Teacher Interaction with ESL Students in a Content-based Classroom dalam TESOL Quaterly Vol 37 No:2 Musim Panas 2003

Hayashi, Keiko. 1999. Reading Strategies and Extensive Reading in EFL Classes. Dalam RELC Journal Vol 30 No: 2 Desember 1999

Hood, S, Solomon, R and Burns, A. 1996. Focus on Reading (New Edition) Sydney National Centre for English Language Teaching and Research.

Huda, Nuril. 1999. Languge Learning and Teaching, Issues and Trends Penerbit IKIP Malang, Malang 
165- Penerapan Metode Pembelajaran Think_Pair-Share-Square .......

Ianchu, Martha. 2000. Implementing Fluency First Activities in an Intermediate Level EAP Reading Class dalam TESOL Journal Vol 9 No:2 Musim Panas 2003

Jacob, E. 1999. Cooperative Learning in Context. An Eductional Innovation in everyday classroom. Albany State University of New York Press.

Jones, R. 2002. Strategies for reading Comprehension, think-pair-share-square, reading Quest Strategies (online) www.clcrc.com

Kemmis, S and McTaggart, R. 1998. The Action Research Planner. Greylong. Deakin University Press.

Lie, Anita. 2002. Cooperative Learning. Mempraktekkan Cooperative Learning di Ruang-ruang Kelas. Grasindo Jakarta.

McNiff, J. 1992. Action Research: Principles and Practice. Kent. Routledge. Chapaman and Hall.

Shih, May. 1999. More than Practising Language Communicative Reading and Writing for Asian Setting dalam TESOL Journal Vol 8 No:4 Musim Dingin 1999.

Snow. C 2002. Reading for Understanding Arlington. Scince and Technology Policy Institute.

Sutarsyah. 2000. Students' Reading Problems and Strategies. Disertasi Doktor Universitas Negeri Malang, tidak diterbitkan. 